\title{
TEKNIK PENYIMPANAN SEMAI CEMPAKA WASIAN (Magnolia tsiampaca (Miq.) Dandy) MENGGUNAKAN ZAT PENGHAMBAT TUMBUH DAN PERLAKUAN MEDIA TANAM
}

\author{
(The Techniques of Storing Cempaka Wasian (Magnolia tsiampaca (Miq.) Dandy) using \\ Growth Inhibitor and Planting Media Treatment)
}

\section{Arif Irawan, Jafred E Halawane, dan/and Hanif Nurul Hidayah}

Balai Penelitian Kehutanan Manado

J1. Tugu Adipura Raya Kel. Kima Atas Kec. Mapanget, Kota Manado, Sulawesi Utara, Indonesia Telp : (0431) 3666683

E-mail : arif_net23@yahoo.com

Tanggal diterima: 25 Maret 2015; Tanggal direvisi: 26 April 2018; Tanggal disetujui: 28 Oktober 2018

\begin{abstract}
Cempaka wasian (Magnolia tsiampaca (Miq) Dandy) is a forest tree species that has recalcitrant seed character. Recalcitrant seeds are difficult to be stored for a long period, thus storing the seedlings can be considered as an option. This research aims to determine the effect of growth inhibitors and planting media on seedling growth during storage. The inhibitors used were paclobutrazol $250 \mathrm{ppm}, \mathrm{NaCl} 0,5 \%$ and aquadest (as control treatment). The media used consisted of top soil+cocopeat (1:1), top soil+sand(1:1) and top soil+husk charcoal (1:1). The research design used was a complete randomized factorial pattern design. The results showed that the inhibitors had a significant effect on the growth os seedling height. Provision of 250 ppm paclobutrazol was able to inhibit the growth of seedling height. Planting media also had a significant effect on the growth of height and diameter of the seedlings, also on seed quality index of cempaka wasian. The soil+cocopeat and soil+sand planting media are effective to reduce the growth rate in both height and diameter of cempaka wasian seedlings during storage.
\end{abstract}

Key words: Cempaka, growth inhibitors, planting media, seedling

\begin{abstract}
ABSTRAK
Cempaka wasian (Magnolia tsiampaca (Miq) Dandy) adalah salah satu jenis pohon hutan yang memiliki karakter benih rekalsitran yang sulit disimpan dalam jangka waktu lama, sehingga perlu dilakukan penyimpanan dalam bentuk semai dengan menggunakan bahan semai. Tujuan penelitian ini adalah untuk mengetahui pengaruh bahan penghambat pertumbuhan dan media tanam terhadap pertumbuhan semai cempaka wasian selama masa penyimpanan. Bahan penghambat pertumbuhan yang digunakan adalah paklobutrazol 250 ppm, $\mathrm{NaCl} 0,5 \%$, dan akuades sebagai kontrol. Media tanam terdiri dari tanah+cocopeat (1:1), tanah+pasir (1:1), dan tanah+arang sekam (1:1). Rancangan percobaan yang digunakan adalah rancangan acak lengkap pola faktorial. Hasil penelitian menunjukkan faktor zat penghambat tumbuh memberikan pengaruh yang nyata terhadap pertumbuhan tinggi bibit. Pemberian paklubutrazol $250 \mathrm{ppm}$ mampu menghambat pertumbuhan tinggi bibit. Faktor media tanam memberikan pengaruh nyata terhadap pertumbuhan tinggi, diameter, dan indeks mutu bibit cempaka wasian. Media tanam tanah+sabut kelapa dan tanah+pasir merupakan media yang efektif mengurangi kecepatan pertumbuhan tinggi dan diameter semai cempaka wasian selama penyimpanan.
\end{abstract}

Kata kunci: Cempaka, bahan penghambat pertumbuhan, media tanam, semai

\section{PENDAHULUAN}

Teknik penyimpanan tanaman dalam bentuk semai adalah metode yang dapat dilakukan dalam perbanyakan tanaman khususnya untuk tanaman yang memiliki benih rekalsitran. Jenis benih rekalsitran memiliki sifat mudah mengalami penurunan viabilitas secara cepat, sehingga sulit disimpan dalam jangka waktu yang lama. Secara umum bahwa tipe benih rekalsitran akan mempertahankan kadar air tinggi dan sangat peka terhadap pengeringan. 
Penurunan kadar air menjadi salah satu penyebab kemunduran benih rekalsitran secara cepat yang ditandai dengan penurunan daya berkecambah benih (Kusmana, Kalingga, \& Syamsuwida, 2011). Pertumbuhan semai selama penyimpanan dapat ditekan dengan memberi bahan kimia ramah lingkungan yang dapat menghambat pertumbuhan vegetatif, seperti triazole, benzoat atau garam mineral (Syamsuwida \& Aminah, 2010). Penggunaan zat paklubutrazol (triazole) dan $\mathrm{NaCl}$ (garam mineral) merupakan dua jenis bahan yang sering digunakan untuk tujuan ini. Paklubutrazol pertama kali dikembangkan oleh Imperial Chemical Industries (ICI) Amerika Serikat sebagai suatu zat penghambat tumbuh yang potensial untuk tanaman ornamental dan agronomi. Paklubutrazol telah banyak digunakan seperti pada anggrek Gramatophyllum (Habibah \& Sumadi, 2013), kakao (Abdillah, Dewi, \& Rosniawaty, 2014), dan cengkeh (Runtunuwu, 2011). NaCl sering digunakan karena kandungan $\mathrm{Na}^{+}$dan $\mathrm{Cl}^{-}$yang terserap tanaman akan memengaruhi pertumbuhan tanaman mulai dari tinggi tanaman, perkembangan daun, dan bobot kering tanaman (Hussein, Balbaa, \& Gaballah, 2007). Pemberian $\mathrm{NaCl}$ dapat menghambat pembesaran sel yang mengakibatkan tanaman akan tumbuh menjadi kerdil karena adanya pengaruh cekaman osmotik, sehingga tanaman sulit menyerap air dan pengaruh racun dari ion $\mathrm{Na}^{+}$dan $\mathrm{Cl}^{-}$(Dachlan, Kasim, \& Sari, 2013). Selanjutnya Triyani, Suwarto, \& Nurchasanah (2013) juga menyatakan bahwa perlakuan $\mathrm{NaCl}$ menyebabkan jumlah air dalam tanaman berkurang, sehingga turgor sel-sel penutup stomata turun. Penurunan turgor stomata mengakibatkan proses fotosintesis terhambat sehingga jumlah asimilat yang dihasilkan oleh tanaman semakin berkurang. Penelitian Ashraf \& Foolad (2007) menyatakan bahwa cekaman garam $\mathrm{NaCl}$ menyebabkan berbagai efek pada fisio- logis tanaman seperti laju respirasi meningkat, toksisitas ion, perubahan pertumbuhan tanaman, distribusi mineral, dan ketidakstabilan membran yang dihasilkan dari perpindahan kalsium oleh natrium, permeabilitas membran, dan penurunan tingkat fotosintetik. Perlakuan $\mathrm{NaCl}$ menekan potensi tumbuhan dalam membentuk akar yang ditunjukkan dengan jumlah akar yang lebih rendah pada tanaman kapas (Sulistyowati, Sumartini, \& Aminah, 2010), menghambat pertumbuhan jagung dan rumput teki (Cyperus rotundus) (Pranasari, Tutik, \& Purwani, 2012), dan mampu meningkatkan hasil dan mutu buah tomat (Rahmawati, Sulistyaningsih, \& Putra, 2011).

Selain penggunaan zat penghambat tumbuh, media tanam juga dapat menjadi faktor penentu dalam keberhasilan penyimpanan tanaman dalam bentuk semai. Syamsuwida, Aminah, \& Hidayat (2010) melaporkan bahwa kondisi optimum penyimpanan semai mimba (Azadirachta indica) adalah di bawah kondisi naungan ringan dengan pemberian bahan penghambat tumbuh paklubutrazol $250 \mathrm{ppm}$ dan penggunaan media tanam pasir.

Cempaka wasian (Magnolia tsiampaca (Miq.) Dandy) adalah salah satu jenis kayu pertukangan yang banyak diminati oleh masyarakat di Sulawesi Utara. Benih cempaka wasian termasuk benih rekalsitran atau tidak dapat disimpan dalam waktu lama karena viabilitasnya yang rendah (Kinho \& Mahfudz, 2011). Pramono \& Rustam (2017) menyatakan bahwa benih cempaka atau bambang lanang termasuk jenis rekalsitran karena memiliki kandungan air dan lemak yang tinggi dan tidak ditemukannya fase pengeringan benih (maturation drying) selama perkembangan benih. Cempaka wasian tidak menghasilkan buah yang berlimpah sepanjang tahun, sehingga terdapat kesulitan dalam penyediaan bibit untuk 
kebutuhan penanaman jika tidak bertepatan dengan produksi benih. Mengantisipasi permasalahan ini maka cara yang dapat dilakukan adalah dengan melakukan penyimpanaan dalam bentuk semai di persemaian melalui teknik penghambatan pertumbuhan bibit

Penelitian ini bertujuan untuk mengetahui pengaruh penggunaan zat penghambat tumbuh dan media tanam terhadap pertumbuhan semai cempaka wasian di persemaian.

\section{METODOLOGI}

\section{A. Waktu, Lokasi dan Bahan Penelitian}

Penelitian dilaksanakan di persemaian Balai Penelitian dan Pengembangan Lingkungan Hidup dan Kehutanan Manado. Area persemaian berada pada ketinggian $70 \mathrm{~m}$ di atas permukaan laut (dpl) dengan temperatur udara antara 29$34^{\circ} \mathrm{C}$ dan kelembaban udara 40-70\%. Penelitian dilaksanakan selama enam bulan pada bulan April hingga Oktober 2014.

Bahan yang digunakan dalam penelitian ini adalah semai cempaka wasian umur 2 bulan. Zat penghambat tumbuh yang diujikan adalah paklubutrazol dan $\mathrm{NaCl}$. Perlakuan media simpan yang dipakai yaitu tanah top soil, pasir, sabut kelapa (cocopeat), dan arang sekam.

\section{B. Metode}

\section{Prosedur kerja}

Perkecambahan benih cempaka wasian dilakukan pada bak plastik menggunakan media pasir. Perkecambahan benih berlangsung pada 10-14 hari setelah penaburan dan bibit siap disapih satu minggu setelahnya. Pada awalnya bibit disapih pada media yang sama yaitu media top soil. Selanjutnya saat bibit telah berumur dua bulan, bibit dipindahkan sesuai dengan perlakuan media simpan yang digunakan dan aplikasi pemberian zat penghambat tumbuh dengan cara penyemprotan terhadap daun. Penyemprotan dilakukan satu kali pada awal pengamatan sebanyak $3 \mathrm{ml}$ per bibit. Perlakuan zat penghambat tumbuh adalah paklobutrazol (250 ppm), $\mathrm{NaCl}(0,5 \%)$ dan akuades sebagai kontrol. Larutan paklobutrazol $250 \mathrm{ppm}$ dipersiapkan dengan cara melarutkan $1 \mathrm{ml}$ paklubutrazol $250 \mathrm{~g} / \mathrm{l}$ bahan aktif ke dalam akuades hingga $1.000 \mathrm{ml}$. Larutan $\mathrm{NaCl}$ $0,5 \%$ dibuat dengan cara melarutkan $\mathrm{NaCl}$ $5 \mathrm{~g}$ ke dalam akuades hingga $1.000 \mathrm{ml}$. Dosis paklobutrazol dtentukan berdasarkan hasil penelitian Syamsuwida et al. (2010) sedangkan dosis $\mathrm{NaCl}$ ditentukan berdasarkan hasil penelitian Syamsuwida \& Aminah (2011). Semai disimpan selama enam bulan pada bedeng persemaian pada kondisi ternaung dengan intensitas cahaya \pm 37.350 lux.

\section{Rancangan percobaan}

Rancangan percobaan yang digunakan adalah Rancangan Acak Lengkap pola Faktorial (3x3). Faktor pertama zat penghambat pertumbuhan (A) terdiri atas tiga taraf (Paklubutrazol, $\mathrm{NaCl}$, dan aquades/kontrol). Faktor kedua media tanam (B) terdiri atas tiga taraf (tanah+sabut kelapa (1:1), tanah+pasir (1:1), dan tanah+arang sekam (1:1)). Masing-masing kombinasi perlakuan diulang sebanyak tiga kali dengan jumlah setiap ulangan terdiri dari enam bibit.

\section{Pengamatan parameter pertum- buhan}

Pengamatan pertumbuhan tanaman dilakukan setelah enam bulan pemberian perlakuan. Parameter pertumbuhan yang diamati adalah tinggi bibit, diameter bibit, indeks mutu bibit (IMB), dan persen hidup.

Tinggi diukur mulai dari pangkal batang hingga titik tumbuh bibit. Diameter batang diukur pada ketinggian $1 \mathrm{~cm}$ di atas pangkal batang. 
Indeks mutu bibit dihitung menggunakan rumus Dickson (1960) :

$\mathrm{IMB}=\frac{\text { Bobot kering batang }(\mathrm{gr})+\text { Bobot kering akar }(\mathrm{gr})}{\frac{\text { Tinggi }(\mathrm{cm})}{\text { Diameter }(\mathrm{mm})}+\frac{\text { Bobot kering batang }(\mathrm{gr})}{\text { Bobot kering akar }(\mathrm{gr})}}$

\section{Analisis Data}

Data pengamatan yang diperoleh dianalisis dengan uji $\mathrm{F}$ (analisis varian). Apabila hasil uji $\mathrm{F}$ berbeda nyata maka dilanjutkan dengan uji jarak berganda Duncan (DMRT).

\section{HASIL DAN PEMBAHASAN}

\section{A. Hasil}

Berdasarkan analisis varian (Tabel 1) dapat diketahui bahwa perlakuan media tanam memberikan pengaruh nyata terhadap pertumbuhan tinggi, diameter dan indeks mutu bibit cempaka wasian, sedangkan perlakuan zat penghambat tumbuh hanya memberikan pengaruh yang nyata terhadap pertumbuhan tinggi bibit. Perlakuan interaksi antara zat penghambat tumbuh dan media tanam tidak memberikan pengaruh terhadap semua parameter yang diamati. Selain itu dapat diketahui juga bahwa perlakuan dari percobaan yang dilakukan tidak memberikan pengaruh nyata terhadap persen hidup bibit cempaka wasian. Hal ini mengindikasikan bahwa tidak terjadi kecenderungan penurunan persen hidup bibit berdasarkan teknik penyimpanan semai cempaka wasian yang telah dilakukan.

Berdasarkan hasil analisis varian pada Tabel 1, selanjutnya dilakukan uji lanjut dengan menggunakan uji jarak berganda Duncan (DMRT) yang ditampilkan pada Tabel 2.

Berdasarkan Tabel 2 dapat diketahui perlakuan zat penghambat tumbuh paklubutrazol dan media tanam tanah+cocopeat memberikan nilai rata-rata pertumbuhan tinggi dan diameter bibit cempaka wasian terkecil walaupun secara statistik tidak memiliki perbedaan yang nyata.

\section{B. Pembahasan}

Penggunaan bahan penghambat tumbuh dan media tanam yang tepat merupakan salah satu metode yang digunakan untuk menghambat pertumbuhan tanaman sebagai salah satu teknik penyimpanan semai. Metode penghambatan yang dapat dilakukan adalah dengan menekan pertumbuhan vegetatif tanaman, sehingga hal ini diharapkan mampu berpengaruh terhadap perkembangan organ tanaman lainnya.

Tabel (Table) 1. Analisis varian tinggi, diameter, indeks mutu bibit, dan persen hidup $M$. tsiampaca (Analysis of variance in height growth, diameter, seed quality index and survival rate of $\underline{\mathrm{M}}$. tsiampaca)

\begin{tabular}{|c|c|c|c|c|c|c|c|c|}
\hline \multirow[t]{2}{*}{$\begin{array}{c}\text { Sumber variasi } \\
\text { (Source of variant) }\end{array}$} & \multicolumn{2}{|c|}{$\begin{array}{l}\text { Tinggi } \\
\text { (Height) }\end{array}$} & \multicolumn{2}{|c|}{$\begin{array}{l}\text { Diameter } \\
\text { (Diameter) }\end{array}$} & \multicolumn{2}{|c|}{$\begin{array}{l}\text { Indeks mutu bibit } \\
\text { (Seed quality index) }\end{array}$} & \multicolumn{2}{|c|}{$\begin{array}{c}\text { Persen hidup } \\
\text { (Survival } \\
\text { percentage) }\end{array}$} \\
\hline & F-hit & $\operatorname{Pr}<\mathrm{F}$ & F-hit & $\operatorname{Pr}<\mathrm{F}$ & F-hit & $\operatorname{Pr}<\mathrm{F}$ & F-hit & $\operatorname{Pr}<F$ \\
\hline $\begin{array}{l}\text { Zat penghambat } \\
\text { tumbuh (Growth } \\
\text { inhibitor) }\end{array}$ & $11,14^{*}$ & 0,001 & 36,24 & 0,594 & 0,49 & 0,617 & 1,00 & 0,387 \\
\hline $\begin{array}{l}\text { Madia tanam } \\
\text { (Planting media) }\end{array}$ & $25,91 *$ & 0,001 & $0,52^{*}$ & 0,001 & $36,73^{*}$ & 0,001 & 0,14 & 0,287 \\
\hline $\begin{array}{l}\text { Interaksi } \\
\text { (Interaction) }\end{array}$ & 1,36 & 0,250 & 1,71 & 0,158 & 0,35 & 0,846 & 0,36 & 0,836 \\
\hline
\end{tabular}

Keterangan (Remarks) : * = Berbeda nyata pada taraf uji 0,05 (Significantly different at 5\% test level) 
Tabel (Table) 2. Uji beda nyata pengaruh bahan penghambat tumbuh dan media tanam terhadap pertambahan tinggi cempaka wasian umur bibit 8 bulan (Result of the Duncan multiple range test of the effect of growth inhibitors and planting media on the height increment of 8 month age seedlings of cempaka wasian)

\begin{tabular}{lccc}
\hline \multicolumn{1}{c}{$\begin{array}{c}\text { Faktor } \\
\text { (Factors) }\end{array}$} & $\begin{array}{c}\text { Tinggi } \\
(\text { Height }) \\
(\mathrm{cm})\end{array}$ & $\begin{array}{c}\text { Diameter } \\
\text { (Diameter) } \\
(\mathrm{mm})\end{array}$ & $\begin{array}{c}\text { Indeks mutu } \\
\text { bibit } \\
\text { (Seed quality } \\
\text { index })\end{array}$ \\
\hline $\begin{array}{l}\text { Faktor zat penghambat (Growth inhibitor } \\
\text { factors) }\end{array}$ & & & \\
NaCl $(\mathrm{NaCl})$ & $11,02 \mathrm{a}$ & $2,08 \mathrm{a}$ & $0,43 \mathrm{a}$ \\
$\begin{array}{l}\text { Aquades (Aquades) } \\
\text { Paklubutrazol (Paclubutrazol) }\end{array}$ & $9,19 \mathrm{~b}$ & $1,98 \mathrm{a}$ & $0,39 \mathrm{a}$ \\
$\begin{array}{l}\text { Faktor media tanam (Planting media factors) } \\
\text { Tanah+arang sekam (Top soil + husk }\end{array}$ & $8,57 \mathrm{~b}$ & $1,93 \mathrm{a}$ & $0,39 \mathrm{a}$ \\
charcoal) & $11,67 \mathrm{a}$ & $2,61 \mathrm{a}$ & $0,61 \mathrm{a}$ \\
$\begin{array}{l}\text { Tanah+pasir (Top soil+sand) } \\
\text { Tanah+cocopeat (Top soil+cocopeat) }\end{array}$ & $8,98 \mathrm{~b}$ & $1,81 \mathrm{~b}$ & $0,33 \mathrm{~b}$ \\
\hline
\end{tabular}

Keterangan (Remarks) : Huruf yang berbeda menunjukkan berbeda nyata pada taraf uji 0,05 (Different letters indicate significant difference at $5 \% \%$ test level)

Berdasarkan hasil penelitian ini diketahui bahwa rata-rata pertumbuhan tinggi dan diameter bibit cempaka wasian selama penyimpanan menunjukkan adanya kecenderungan meningkat, namun dengan pertambahan yang relatif rendah. Secara keseluruhan bibit cempaka wasian memberikan respon positif terhadap penggunaan paklubutrazol, hal ini nampak dari adanya penghambatan pertumbuhan sebagai dampak dari adanya aplikasi paklubutrazol $250 \mathrm{ppm}$. Larutan paklubutrazol $250 \mathrm{ppm}$ yang disemprotkan pada bagian daun cempaka wasian memberikan pengaruh signifikan terhadap pertumbuhan vegetatifnya. Perkembangan ukuran daun yang cenderung lebih kecil merupakan salah satu efek yang diberikan larutan paklubutrazol $250 \mathrm{ppm}$ melalui mekanisme penghambatan biosintesis hormon giberelin (Lienargo, Runtunuwu, Rogi, \& Tumewu, 2014). Salah satu peran giberelin yaitu dalam proses pemanjangan sel. Dengan dihambatnya produksi giberelin maka sel terus membelah tapi sel-sel baru tersebut tidak memanjang. Pengaruh fisiologis dari paklobutrazol (retardant) antara lain memperpendek ruas tanaman. Menurut Noor (2009), pemberian paklubutrazol $140 \mathrm{ppm}$ pada anakan Shorea spp. berpengaruh terhadap titik apikal per-tumbuhan, ketebalan daun, dan luasan penampang daun tanaman. Efek langsung terhadap tanaman adalah titik apikel pertumbuhan seakan-akan terhenti dan mempengaruhi fungsi stomata pada daun, sehingga berpengaruh terhadap lambatnya pertumbahan tanaman. Nurnasari \& Djumuli (2011) menyatakan bahwa paklu-butrazol mampu menghambat kebutuhan tanaman terhadap unsur nitrogen. Nitrogen berperan dalam proses metabolisme tanaman terutama pada pembentukan klorofil yang dapat meningkatkan aktivitas fotosintesis, sehingga fotosintat yang dihasilkan semakin besar (Lutfi, 2007). Unsur $\mathrm{N}$ memiliki peran penting pada fase vegetatif, antara lain untuk pembentukan sel-sel baru seperti daun, cabang, dan mengganti sel-sel yang rusak. Metode penghambatan menggunakan paklubutrazol 250 ppm yang pernah dilakukan berhasil menekan pertumbuhan semai bakau (Syamsuwida et al., 2010).

Respon bibit cempaka wasian terhadap perlakuan pemberian $\mathrm{NaCl} 0,5 \%$ dalam penelitian ini adalah tidak menekan 
pertumbuhan bibit, namun bersifat sebaliknya. Perlakuan $\mathrm{NaCl} 0,5 \%$ memberikan pertumbuhan lebih baik dibandingkan perlakuan kontrolnya (akuades). Hal ini diduga karena kandungan $\mathrm{NaCl}$ 0,5\% memberikan unsur tambahan yang positif untuk pertumbuhan semai cempaka wasian. Konsentrasi $\mathrm{NaCl}$ $0,5 \%$ mungkin terlalu kecil untuk digunakan dalam menghambat pertumbuhan pada jenis cempaka wasian dibandingkan untuk jenis lain yang pernah dilakukan pada penelitian-penelitian sebelumnya. Asih, Mukarlina, \& Lovadi (2015) menyatakan bahwa respon tumbuhan terhadap peningkatan konsentrasi $\mathrm{NaCl}$ berbeda-beda tergantung jenis tanaman. Konsentrasi $\mathrm{NaCl}$ yang tinggi dapat meningkatkan atau menurunkan tingkat pertumbuhan pada tanaman. Kandungan unsur Natrium $\left(\mathrm{Na}^{+}\right)$ mempunyai fungsi yang sama seperti unsur Kalium $\left(\mathrm{K}^{+}\right)$, sehingga dapat menggantikan fungsi dari Kalium $\left(\mathrm{K}^{+}\right)$ dalam mempertahankan kadar air di daun. Jumberi (2006) menyatakan bahwa pengaruh $\mathrm{Na}^{+}$akan sangat besar bila pasokan $\mathrm{K}^{+}$bagi tanaman tidak mencukupi. Lebih lanjut bahwa unsur ini dapat mengurangi pengaruh yang ditimbulkan oleh ke-kurangan $\mathrm{K}^{+}$tapi tidak dapat mengganti-kan fungsi $\mathrm{K}^{+}$ sepenuhnya. Dalam konteks fotosistesis, $\mathrm{Na}^{+}$merupakan unsur yang esensial bagi tanaman. Pentingnya $\mathrm{Na}$ bagi tanaman adalah dalam hal osmoregulation, dan pemeliharaan turgor serta untuk mengontrol aktifitas stomata. Sedangkan klor (Cl) menurut Sudarmi (2013) merupakan unsur hara esensial yang selalu dibutuhkan tanaman walaupun dalam jumlah sedikit yang berfungsi merangsang aktivitas beberapa enzim untuk mempengaruhi penyerapan air pada jaringan tumbuhan.

Selain zat penghambat tumbuh, perlakuan media tanam juga memberikan pengaruh yang cukup signifikan dalam hal menekan pertumbuhan semai cempaka wasian. Media tanah+cocopeat merupakan media yang paling efektif dalam menekan pertumbuhan semai cempaka wasian. Berdasarkan analisis kandungan senyawa kimia dari ketiga media yang dicobakan (Lampiran 1), diketahui bahwa media tanah+cocopeat memiliki kandungan unsur $\mathrm{N}$ (Nitrogen) yang sangat kecil $(0,01)$. Namun di sisi lain media tanah+cocopeat juga memiliki kandungan C organik yang paling tinggi $(5,97)$. Afandi, Siswanto, \& Nuraini (2015) menyatakan bahwa karbon merupakan sumber makanan mikroorganisme tanah, sehingga keberadaan $\mathrm{C}$ organik dalam tanah akan memacu kegiatan mikroorganisme, sehingga meningkatkan proses dekomposisi tanah. Tetapi tingginya kandungan $\mathrm{C}$ organik dalam media tanah+cocopeat ini diketahui tidak memberikan pengaruh terhadap pertumbuhan cempaka wasian, karena diduga kandungan $\mathrm{C}$ organik yang terdapat dalam media belum terdekomposisi secara sempurna. Hasil perbandingan kandungan pada media ini sejalan dengan hasil penelitian Ramadhan (2017) yang menyatakan bahwa hasil pengujian terhadap media cocopeat menunjukkan bahwa nilai $\mathrm{C}$ media ini sangat tinggi, sedangkan nilai kandungan $\mathrm{N}$ adalah sangat rendah. Pandebesie \& Rayuanti (2012) menambahkan bahwa nilai $\mathrm{C} / \mathrm{N}$ yang tinggi menunjukkan unsur hara tersedia dalam jumlah yang rendah karena bahan organik belum terdekomposisi.

Rendahnya kandungan unsur $\mathrm{N}$ dalam media sapih tanah+cocopeat diduga karena pengaruh sifat media cocopeat yang memiliki kemampuan untuk mengikat air yang tinggi. Hasriani, Kalsim, \& Sukendro (2013) menyatakan bahwa media sapih cocopeat memiliki kadar air dan daya simpan air masingmasing sebesar $119 \%$ dan 695,4\%. Media cocopeat memiliki pori mikro yang mampu menghambat gerakan air lebih besar, sehingga menyebabkan ketersediaan air lebih tinggi (Istomo \& Valentino, 
2012) . Pada saat tertentu, kondisi tersebut menyebabkan pertukaran gas pada media mengalami hambatan karena media mulai jenuh oleh air. Sifat media yang cenderung tergenang ini diduga mengakibatkan rendahnya kandungan unsur $\mathrm{N}$ pada media sapih tanah+cocopeat. Hardjowigeno (2003) menyatakan bahwa kondisi lahan yang masih tergenang dengan drainase buruk serta ventilasi udara kurang baik dapat memicu proses denitrifikasi dan juga volatilisasi dalam bentuk $\mathrm{NH}_{3}$ (amonia).

Dari hasil uji lanjut diketahui media tanam tanah+pasir juga menunjukkan kemampuan yang tidak jauh berbeda dengan media tanam tanah+cocopeat dalam hal menghambat pertumbuhan tanaman. Media tanam tanah+pasir memiliki porositas yang terlalu tinggi, sehingga tidak mampu menahan air untuk kebutuhan tanaman (Naibahado et al., 2016). Hal ini yang diduga menjadi faktor penyebab lambatnya pertumbuhan tanaman/bibit. Media tanah+pasir merupakan salah satu substrat pertumbuhan tanaman yang memiliki kemampuan mengikat air yang cukup rendah (Sinulingga \& Darmanti, 2008). Media tanam pasir memiliki pori-pori makro yang bersifat mudah meloloskan air dan cepat kering oleh proses penguapan, sehingga berpengaruh terhadap pertumbuhan bibit cempaka wasian.

Nilai indeks mutu bibit semai cempaka wasian dari perlakuan bahan penghambat tumbuh paklubutrazol 250 ppm dan media tanah+cocopeat juga menunjukkan nilai terkecil $(0,39$ dan 0,28$)$ walaupun tidak berbeda nyata secara statistik. Namun demikian, meskipun memiliki nilai terkecil, nilai indeks mutu bibit untuk perlakuan tersebut masih berada dalam kategori nilai yang baik. Nilai indeks mutu bibit indentik dengan tingkat kualitas dan kemampuan bibit untuk tumbuh dengan baik di lapangan. Junaedi \& Hidayat (2009) menyatakan bahwa semakin besar nilai indeks mutu bibit menandakan semakin tinggi mutu bibit dan sebaliknya bibit dengan nilai indeks mutu bibit lebih kecil dari 0,09 akan berdaya tahan hidup yang rendah jika ditanam di lapangan. Nilai indeks mutu bibit cempaka wasian dari perlakuan penghambatan ini diharapkan akan meningkat seiring dengan pertumbuhan semai hingga siap untuk ditanam. Perlakuan lanjutan dapat dilakukan untuk meningkatkan nilai indeks mutu bibit sekaligus untuk menghilangkan pengaruh perlakuan penggunaan bahan penghambat tumbuh paklubutrazol. Salah satu cara efektif untuk menghilangkan pengaruh tersebut adalah melalui penambahan giberelin eksogen (Giberelin (GA3) atau biasa dikenal dengan Gibrecid -T (GA3 20\%)) yang berperan dalam memacu proses pertumbuhan dan perkembangan tanaman serta mendorong perpanjangan dan perbesaran diameter batang (Kusumawati, Endah, \& Nintya, 2009). Perlakuan tambahan ini diharapkan mampu mengembalikan proses pertumbuhan vegetatif bibit cempaka wasian selain juga mengatasi kekerdilan yang berkelanjutan. Perlakuan penambahan GA3 sebaiknya dilakukan di persemaian sebelum waktunya ditanam ke lapangan agar bibit dapat langsung tumbuh normal lagi.

\section{KESIMPULAN DAN SARAN}

\section{A. Kesimpulan}

Teknik yang dapat digunakan untuk menyimpan semai cempaka wasian adalah dengan menggunakan perlakuan penyemprotan zat penghambat tumbuh paklobutrazol $250 \mathrm{ppm}$ pada daun dan menggunakan media tanam tanah+ cocopeat atau media tanam tanah+pasir.

\section{B. Saran}

Teknik penyimpanan cempaka wasian dalam bentuk semai dengan bantuan zat pengatur tumbuh paklobutrazol dapat menjadi solusi altenatif dari permasalahan ketersediaan materi untuk 
kegiatan penanaman dalam jangka panjang.

\section{UCAPAN TERIMA KASIH}

Penelitian ini dibiayai DIPA Balai Penelitian Kehutanan Manado tahun 2014. Ucapan terima kasih kami sampaikan kepada Yeremias Kafiar dan Melkianus S Divi atas bantuannya dalam pelaksanaan penelitian.

\section{DAFTAR PUSTAKA}

Abdillah, H., Dewi, I.R., \& Rosniawaty, S. (2014). Pengaruh pemberian paclobutrazol untuk menekan layu pentil (Cherelle wilt) pada buah kakao (Theobroma cacao L.). Agric. Sci. J I, 4, 39-47.

Afandi, F, N., Siswanto, B., \& Nuraini, Y. (2015). Pengaruh pemberian berbagai jenis bahan organik terhadap sifat kimia tanah pada pertumbuhan dan produksi tanaman ubi jalar di Entisol Ngrakah Pawon, Kediri. Jurnal Tanah dan Sumberdaya Lahan, 2(2), 237-244.

Ashraf \& Foolad, M.R. (2007). Improving plant abiotic-stress resistance by exogenous application of osmoprotectants glycine betaine and proline”, J. Environ. J. Environ, 59, 206-216.

Asih, E.D., Mukarlina., \& Lovadi, L. (2015). Toleransi tanaman sawi hijau (Brassica juncea L.) terhadap cekaman salinitas garam $\mathrm{NaCl}$. Jurnal Protobiont, 4(1), 203-208.

Dachlan, A., Kasim, A., \& Sari, A.. K. (2013). Uji ketahanan salinitas beberapa varietas jagung (Zea mays L.) dengan menggunakan agen seleksi NaCl. Biogenesis, 1(1), 9-17.

Dikson, A. Leaf, A.L., Hosner, L.F. 1960. Quality appraisal of white spruce and white pine seedling stock in nurseries. Forestry Chronicle , 36, 10-13
Habibah, N, A., \& Sumadi. (2013). Konservasi tanaman anggrek Gramatophyllum secara in vitro melalui pertumbuhan minimal menggunakan paclobutrazol. Jurnal MIPA, 36(1), 8-13.

Hardjowigeno, S. (2003). Ilmu Tanah. Akademika Presindo. Jakarta.

Hasriani, Kalsim, D.K., \& Sukendro, A. (2013). Kajian serbuk sabut kelapa (cocopeat) sebagai media tanam. Skripsi. Fakultas Teknologi Pertanian. Institut Pertanian Bogor.

Hussein, M.M., Balbaa, L.K., \& Gaballah, M. (2007). Salicylic acid andsalinity effects on growth of maize plants. Research Journal of Agriculture and Biological Sciences, 3(4), 321-328.

Istomo \& Valentino, N. (2012). Pengaruh pengaturan kombinasi media terhadap pertumbuhan anakan cabutan tumih (Combretocarpus rotundatus (Miq.) Danser). Jurnal Silvikultur Tropika 3(2):81-84.

Jumberi. (2006). Pemanfaatan hara air laut untuk memenuhi kebutuhan tanaman. Balai Pengkajian Teknologi Pertanian Sumatra Utara

Junaedi, A., Hidayat A, \& Frianto, D. (2010). Kualitas fisik bibit meranti tembaga (Shorea leprosula Miq.) asal stek pucuk pada tiga tingkat umur. Jurnal Penelitian dan dan Konservasi Alam, VII(3):281-288.

Kinho, J \& Mahfudz. (2011). Prospek pengembangan cempaka di Sulawesi Utara. Manado: Balai Penelitian Kehutanan Manado.

Kusmana, C., Kalingga, M., \& Syamsuwida, D. (2011). Pengaruh media simpan, ruang simpan, dan lama penyimpanan terhadap viabilitas benih Rhizophora stylosa Griff. Jurnal Silvikultur Tropika, 3(1), 82-87.

Kusumawati, A.,Endah, D., \&Nintya, S. (2009). Pertumbuhan dan 
pembungaan tanaman jarak pagar setelah penyemprotan GA3 dengan konsentrasi dan frekuensi yang berbeda. Jurnal Penelitian Sains Dan Teknologi, 10(1), 18-29.

Lienargo, B.R., Runtunuwu, S.D., Rogi, J.E.X., \& Tumewu, P. (2014). Pengaruh waktu penyemprotan dan konsentrasi paklubutrazol (PBZ) terhadap pertumbuhan dan produksi tanaman jagung (Zea mays L.) varietas manado kuning. Jurnal Cocos, 4(1), 1-9.

Lutfi, M. A. (2007). Pengaruh pemberian beberapa jenis pupuk daun terhadap kadar $\mathrm{N}$ dan $\mathrm{K}$ total daun serta produksi tanaman cabai besar (Capsicum annum L.) pada Inceptisol Karangploso, Malang. Universitas Brawijaya.

Naibaho, GM., Purba, E., Ginting, J. 2015. Pengaruh media tanam dan panjang slip bahan tanaman terhadap pertumbuhan tanaman vetiver (Vetiveria zizanoides (L.) Nash). Jurnal Online Agroekoteknlogi, 3(4),1367-1374.

Noor, M. (2009). Pengaruh pemberian paklubutrazol terhadap pertumbuhan semai Shorea spp. di persemaian. Jurnal Penelitian Dipterokarpa, 3(2), 21-31.

Nurnasari, E.,\&Djumali. (2011). Respon tanaman jarak pagar (Jatropha curcas L.) terhadap lima jenis zat pengatur tumbuh (ZPT). Buletin Tanaman Tembakau, Serat \& Minyak Industri, 3(2), 71-79.

Pandebesie, E.S., \& Rayuanti, D. (2012). Pengaruh penambahan sekam pada proses pengomposan sampah domestik. Jurnal Lingkungan Tropis, 6(1), $31-40$.

Pramono, A, A., \&Rustam, E. (2017). Perubahan kondisi fisik, fisiologis, dan biokimia benih Michelia champaca pada berbagai tingkat kemasakan. Prosiding Seminar Nasional Masyarakat Biodeversitas Indonesia, 1(1), 368-375.

Pranasari, R.A., Tutik, N., \& Purwani, K. (2012). Persaingan tanaman jagung (Zea mays) dan rumput teki (Cyperus rotundus) pada pengaruh cekaman garam (NaCl). Jurnal Sains Dan Seni ITS, 1(10), 54-57.

Rahmawati, H., Sulistyaningsih, E., \& Putra, E. T. S. (2011). Pengaruh kadar $\mathrm{NaCl}$ terhadap hasil dan mutu buah tomat (Lycopersicum esculentum Mill). Universitas Gadjah Mada.

Ramadhan, D. (2017). Pemanfaatan cocopeat sebagai media tumbuh sengon laut (Paraserianthes falcataria) dan merbau darat (Intsia palembanica). Universitas Lampung.

Runtunuwu, S. D. (2011). Konsentrasi paclobutrazol dan pertumbuhan tinggi bibit cengkeh (Syzygium aromaticum (L.) Merryl \& Perry). Euginia, 17(2), 135-141.

Sudarmi. (2013). Pentingnya unsur hara mikro bagi pertumbuhan tanaman. Widyatama, 22(2), 178-183.

Sinulingga, M. \& Darmanti, S (2008). Kemampuan mengikat air oleh tanah pasir yang diperlakukan dengan tepung rumput laut Gracilaria verrucosa. Fakultas FMIPA, Jurusan Biologi, UNDIP. Semarang.

Sulistyowati, E., Sumartini, S., \& Aminah, A. (2010). Toleransi 60 aksesi kapas terhadap cekaman salinitas pada fase vegetative. Jurnal Littri, 6(1), 20-26.

Syamsuwida, D., \&Aminah, A. (2010). Metode penyimpanan semai bakau (Rhizopora apiculata) dengan berbagai kondisi tempat dan media simpan serta bahan penghambat pertumbuhan. Jurnal Pemuliaan Tanaman Hutan, 4(3), 125-136.

Syamsuwida, D., \&Aminah, A. (2011). . Teknik penyimpanan semai kayu 
bawang (Dysoxylum moliscimum) melalui pemberian zat penghambat tumbuh dan pengaturan naungan. Jurnal Pemuliaan Tanaman Hutan, 8(3), 147-153.

Syamsuwida, D., Aminah, A., \& Hidayat, A. (2010). Pemberian zat pengatur tumbuh untuk menghambat pertumbuhan semai mimba
(Azadirachta indica) selama penyimpanan. Jurnal Penelitian Hutan Tanaman, 7(1), 23-31.

Triyani, A., Suwarto, \& Nurchasanah, S. (2013). Toleransi genotip kedelai (Glycine max 1. Merril.) terhadap konsentrasi garam NACL pada fase vegetatif. Agronomika, 13(1).

Lampiran (Appendix) 1. Kandungan senyawa kimia tanah (The content of soil chemical compounds)

\begin{tabular}{llccccc}
\hline No & \multicolumn{1}{c}{$\begin{array}{c}\text { Media tanam } \\
\text { (Planting media) }\end{array}$} & $\% \mathrm{KA}$ & $\mathrm{pH} \mathrm{H} 2 \mathrm{O}$ & $\mathrm{pH} \mathrm{KCl}$ & $\% \mathrm{~N}$ & $\%$ C Organik \\
\hline 1. & $\begin{array}{l}\text { Tanah+cocopeat } \\
\text { (Top soil+cocopeat) }\end{array}$ & 8,12 & 6,59 & 5,45 & 0,01 & 5,97 \\
2. $\quad \begin{array}{l}\text { Tanah+pasir } \\
\quad \text { (Top soil+sand) }\end{array}$ & 5,94 & 6,45 & 5,50 & 0,27 & 3,62 \\
3. $\quad \begin{array}{l}\text { Tanah+sekam } \\
\text { (Top soil+husk charcoal) }\end{array}$ & 7,7 & 6,66 & 5,25 & 0,36 & 5,3 \\
\hline
\end{tabular}

Sumber (Source): Laboratorium Tanah Balai Penelitian Kelapa dan Palma Lainnya (Soil laboratory of Indonesian Palmae Crops Research Institute) 